Journal of History Culture and Art Research (ISSN: 2147-0626)

Tarih Kültür ve Sanat Araştırmaları Dergisi

Vol. 9, No. 1, March 2020

\title{
DOI: 10.7596/taksad.v9i1.2533
}

Citation: Fedotova, H., Kosilova, O., \& Kobets, M. (2020). Protection of Life and Health of Citizens in The Sphere of Production and Circulation of Medicines and Medical Products: A Legal Aspect. Journal of History Culture and Art Research, 9(1), 30-48. doi:http://dx.doi.org/10.7596/taksad.v9i1.2533

\section{Protection of Life and Health of Citizens in The Sphere of Production and Circulation of Medicines and Medical Products: A Legal Aspect}

\author{
Hanna Fedotova ${ }^{1}$, Olga Kosilova ${ }^{2}$, Maryna Kobets ${ }^{3}$
}

\begin{abstract}
The statistics, listed in the article, prove that the most frequent encroachment on the life and health of citizens in the field of production and circulation of medicines and medical products is the falsification of medicines that is in demand every day and advertised on television and radio; including painkillers, antibiotics, psychotropic substances.

There are a number of factors contributing to the commission of offenses in the sphere of production (manufacturing), storage, sales (realizations), import of medicines.

The sphere of public procurement of medicines remains the most corrupted area of public relations. Thus, the most widespread type of crime in the health sector is theft of budget funds by excessive prices on market prices, when organizing the purchase of medicines, products and medical equipment for health care institutions. The most widespread corruption schemes for public procurement of medicines in Ukraine are the so-called "cartel conspiracies», in other words, behind-the-scenes agreements between companies on the distribution of winning bidding and excess pricing of medicines in the State Register of wholesale and retail prices.

All considered violations require the development of a clear regulatory mechanism at the legislative and regulatory levels of the processes of production, control and marketing of medicinal products; only such actions will contribute to counteracting fraud and illicit circulation of falsified medicines and will provide protection of life and health of citizens.
\end{abstract}

Keywords: Medicines, Falsified medicines, Medical products, Health care, Health crimes.

\footnotetext{
${ }^{1}$ Doctor Juridical Science (Doctor of Law), Associate Professor, State Research Institute Ministry of Internal Affairs of Ukraine, Kyiv, Ukraine, https://orcid.org/0000-0002-7798-3143, e-mail: hannafedotova1980@ukr.net ${ }^{2}$ Candidate Political Science (Ph.D. of Political), Associate Professor, Taras Shevchenko National University, Kyiv, Ukraine, https://orcid.org/0000-0002-5574-3771, e-mail: fedirko@ukr.net

${ }^{3}$ Candidate Juridical Science (Ph.D. of Law), State Research Institute Ministry of Internal Affairs of Ukraine, Kyiv, Ukraine, https://orcid.org/0000-0001-6725-8469, e-mail: marynakobetsmp@gmail.com
} 


\section{Introduction}

On the modern stage circulation of he falsified medicines is confessed by World Health Organization (WHO) and other international organizations, that carry out control after quality of medicines and their turnover, global socio-economic problem of all world community. As evaluated by WHO, part of the falsified medicines that are in turnover at the Ukrainian pharmaceutical market presents $12 \%$ (every tenth pill) from the general volume of medications, and according to given of the sociological questioning for today more than $35 \%$ Ukrainians consider itself the victims of the falsified medications. By an audit conducted the Accounting Chamber according to plan of work on 2018, it is set that during a period 2015-2017 number of operating licenses to realization of economic activity from the production of medicines did not change (table. 1) practically, here amount of operating licenses to be wholesale and retail to trading in medicines increased on $11 \%$, on the import of medicines (except active pharmaceutical ingredient) - on $15 \%$, that up to a point testifies to profitability of these kinds of activities.

\section{[Table-1]}

\begin{tabular}{|c|c|c|c|c|c|}
\hline \multicolumn{2}{|c|}{ Number of licenses } & 2015 & 2016 & 2017 & 01.01 .2018 \\
\hline \multirow{4}{*}{$\begin{array}{l}\text { Acting (at } \\
\text { the beginning } \\
\text { of the year) }\end{array}$} & $\begin{array}{l}\text { Total, } \\
\text { including: }\end{array}$ & 7025 & 7463 & 7817 & 7789 \\
\hline & - production of medicines & 113 & 115 & 113 & 113 \\
\hline & $\begin{array}{l}\text { - production of medicines in pharmacies } \\
\text { conditions, wholesale and retail trade }\end{array}$ & 6729 & 7141 & 7493 & 7465 \\
\hline & $\begin{array}{l}\text { - import of medicines (except for active } \\
\text { pharmaceutical ingredient) }\end{array}$ & 183 & 207 & 211 & 211 \\
\hline \multirow[t]{4}{*}{ During the year } & Issued & 414 & 833 & 537 & - \\
\hline & Reissued & 14 & 39 & 0 & - \\
\hline & Revoked & 113 & 328 & 521 & - \\
\hline & Declared invalid & 24 & 39 & 22 & - \\
\hline
\end{tabular}

Table: 1. Number of licenses for implementation economic activities on the manufacture, import of medicines and wholesale and retail trade them (except active pharmaceutical ingredient) in 2015-2017, as of 01.01.2018.

Thus, $70 \%$ of the names of medicines and $86 \%$ of medical products, which are allowed for use on the territory of Ukraine, foreign production. At the same time, the number of domestic manufacturers of medicines, for three years, in fact, has not changed (Approved by the decision of the Accounting Chamber, n.d.). According to the statistics of the State Service of Ukraine on Medicines and Drugs Control in 2018, territorial bodies of the State Service of Ukraine on Medicines and Drugs Control on execution of the Annual Plan for the implementation of state surveillance (control) measures of the State Service of Ukraine on Medicines and Drugs Control for 2018, approved by the order of the State Service of Ukraine on Medicines and Drugs Control dated 11/29/2017, No. 1113 checked: 968 licensed pharmaceutical practitioners for 2,620 places of activity (pharmacy stores, pharmacies, pharmacy items). According to the results of the inspections, 2084 cases of violation of the law were established, 875 orders / regulations were issued on the need to eliminate the violations detected, 994 samples of medicinal products were selected, 316 administrative protocols were drawn up;

560 licensees of medical practice (private, communal, department medical and preventive establishments; services of blood) after 794 placed realization of activity. Based on the results of the inspections established 1107 cases of violation of legislation are set, 473 binding overs are given out about the necessity of removal of the educed violations, 4 standards of medicines are selected, 82 administrative protocols make up (State Service of Ukraine on Medicines and Drugs Control, 2018, pp. 1-3). Such plenty of cases of violation of legislation specifies on the increase of threats, medicines, that create a serious threat to life, health and welfare of population of Ukraine, related to falsification.

\section{Research problems:}

- analysis of sources the statistics of the State Service of Ukraine on Medicines and Drugs Control; 
- establishing the causes encroaching on the life and health of citizens in the sphere of production and circulation of medicines and medical products;

\section{Materials and Methods}

A legislation is sent to setting activity in the field of making and circulation of medicines and medical products and protection of life and health of citizens in this sphere is contains the row of normatively-legal acts, in particular:

A Law of Ukraine is «On medicines» from a 04.04.1996 № 123/96-BP (with changes) («On medicines» 1996). Law of Ukraine «On public procurement» from 25.12.2015 №922 - VIII (“On Public Procurement," 2015).

Resolution of the Cabinet of Ministers of Ukraine «On approval of the list of medicines and medical products procured on the basis of purchase agreements (agreements) with specialized organizations procuring the use of budget funds in 2016 under the budget program 2301400» Provision of Medical Measures for Certain Government Programs and complex measures of the program nature "dated August 23, 2016, No. 557 ("The Ukrainian government approved medicines procurement under the 2018 budget funds," n.d.).

The procedure for state registration (re-registration) of medicines and the size of the fee for their state registration (re-registration), approved by the Resolution of the Cabinet of Ministers of Ukraine dated May 6, 2005 No. 376 (as amended) (Resolution of the Cabinet of Ministers of Ukraine, 2005).

Order of the Ministry of Health «On approval of the form and description of the registration certificate for a medicines " dated 29.07.2003 No. 358 ("On approval of the form and description of the registration certificate for a medicinal product," n.d.).

The procedure for checking the materials added to the application for state registration of certain medicines, in relation to their volume, approved by the order of the Ministry of Health of Ukraine July 23, 2015, No. 460 ("Order of the ministry of health of Ukraine," 2015).

The procedure for procurement of medicines by health care institutions and institutions financed from the budget, approved by the Resolution of the Cabinet of Ministers of Ukraine dated September 5, 1996 No. 1071 ("On the Procedure for Procurement of Medicines by Public Healthcare Institutions Financed from the Budget," 1996).

The procedure for confirming the conditions of production of medicines to the requirements of proper industrial practice approved by the order of the Ministry of Health of Ukraine dated December 27, 2012 №1130 ("Procedure for confirming the conditions of production of medicinal products to the requirements of proper industrial practice," 2012).

The rules for prescribing prescriptions for medicines and medical products, the Procedure for the dispatch of medicines and medical products from pharmacies and their structural subdivisions, the Instruction on the order of storage, registration and destruction of prescription forms, approved by order of the Ministry of Health of 19.07.2005 № 360 (Procedure for the dispatch of medicines and medical products from pharmacies and their structural subdivisions, 2005).

Regulation on the State Register of Medicines, approved by the Resolution of the Cabinet of Ministers of Ukraine dated March 31, 2006 №411 (Regulation on the State Register of Medicines, 2006).

Regulation on the State Service of Ukraine for Medicines and Drug Control, approved by the Resolution of the Cabinet of Ministers of Ukraine dated August 12, 2015 No. 647 (Regulation on the State Service of Ukraine for Medicines and Drug Control, 2015).

Regulations on the National List of Essential Medicines and the Regulations on the Expert Committee on the Selection and Use of Essential Medicines, approved by the Order of the Ministry of Health of 01.11.2016 
№ 84 (Regulations on the National List of Essential Medicines and the Regulations on the Expert Committee on the Selection and Use of Essential Medicines, 2016).

Resolution of the Cabinet of Ministers of Ukraine dated September 5, 1996 No. 1071 «On the Procedure for Purchasing Medicines by Healthcare Bodies and Bodies financed from the Budget» (On the Procedure for Purchasing Medicines by Healthcare Bodies and Bodies financed from the Budget», 1996).

The procedure for conducting the State Register of Medicines of Ukraine, approved by the Order of the Ministry of Health of Ukraine of May 08, 2014 №314 (The procedure for conducting the State Register of Medicines of Ukraine, 2014).

The procedure for import, supply and use of medicines, medical products exempted from the taxation of value added tax, approved by the Cabinet of Ministers of Ukraine from 02.12.2015 №1153 (The procedure for import, supply and use of medicines, medical products exempted from the taxation of value added tax, 2015).

Order of the Cabinet of Ministers of Ukraine "On the purchase of medicines, medical products and related services with the involvement of specialized organizations that make purchases» dated November 4, 2015, No. 1396-p (On the purchase of medicines, medical products and related services with the involvement of specialized organizations that make purchases», 2015).

The Order of the Ministry of Heals «On Approval of the Procedure for medicines conducting an examination on the authenticity of registration materials for a submitted for state registration with a view to its purchase by a specialized organization» dated November 3, 2015, No. 721 («On Approval of the Procedure for medicines conducting an examination on the authenticity of registration materials for a submitted for state registration with a view to its purchase by a specialized organization»), 2015.

Resolution of the Cabinet of Ministers of Ukraine "Some issues of paying for medicines and medical products with involvement of specialized organizations, who make procurements» dated October 28, 2015, No. 943 ( «Some issues of paying for medicines and medical products with involvement of specialized organizations, who make procurements», 2015).

Resolution of the Cabinet of Ministers of Ukraine "On approval of the list of medicines and medical products procured on the basis of purchase agreements (contracts) with procurement specialized organizations» dated 08.10.2015 No.787 (On approval of the list of medicines and medical products procured on the basis of purchase agreements (contracts) with procurement specialized organizations», 2015).

Resolution of the Cabinet of Ministers of Ukraine «On the prepayment of goods, works and services purchased for budget funds» dated April 23, 2014, No. 117 ( On the prepayment of goods, works and services purchased for budget funds», 2014).

The procedure for the state control of the quality of medicines imported into Ukraine is approved by the Resolution of the Cabinet of Ministers of Ukraine dated 14.09.2005 No. 902 (The procedure for the state control of the quality of medicines imported into Ukraine, 2005).

The procedure for conducting clinical trials of medicines and examination of materials of clinical trials, approved by the Order of the Ministry of Health of September 23, 2009 No. 690 (The procedure for conducting clinical trials of medicines and examination of materials of clinical trials, 2009).

The procedure for verification before issuing a license for conducting economic activity on import of medicinal products, approved by the order of the Ministry of Health of Ukraine dated February 27, 2013 №168 (The procedure for verification before issuing a license for conducting economic activity on import of medicinal products, 2013).

Licensing conditions for conducting economic activity on import of medicines, ratified by an order of the Ministry of Health of Ukraine dated February 20, 2013 №143 (Licensing conditions for conducting economic activity on import of medicines, 2013). 
The procedure for monitoring compliance with the Licensing Conditions for conducting business activities in the production of medicines, wholesale and retail trade in medicines, approved by the order of the Ministry of Health of Ukraine dated October 31, 2011, No. 724 (The procedure for monitoring compliance with the Licensing Conditions for conducting business activities in the production of medicines, wholesale and retail trade in medicines, 2011).

The procedure for checking before issuing a license for conducting economic activity for the production of medicines, wholesale, retail trade in medicines, approved by the order of the Ministry of Health of Ukraine dated 11.07.2012, No. 513 (The procedure for checking before issuing a license for conducting economic activity for the production of medicines, wholesale, retail trade in medicines, 2012).

Procedure for conducting industry certification of laboratories for quality and safety control of medicines, approved by the order of the Ministry of Health of Ukraine of 14.01.2004 № 10 (Procedure for conducting industry certification of laboratories for quality and safety control of medicines, 2004).

Order of the Ministry of Health of Ukraine dated January 21, 2013, No. 39 «On approval of forms of Documents Applicable to the State Control of the quality of medicines Imported into Ukraine».

The procedure for the certification of the quality of medicines for international trade and confirmation for the active pharmaceutical ingredients being exported is approved by the order of the Ministry of Health of Ukraine dated December 7, 2012 No. 1008.

The procedure for conducting examination of materials for medicines submitted for state registration (reregistration), as well as examination of materials on amendments to registration materials during the validity of the registration certificate, approved by the order of the Ministry of Health of Ukraine of 26.08.2005, No. 426.

Licensing conditions for conducting business activities for the production of medicines, wholesale and retail trade in medicinal products, approved by the order of the Ministry of Health of Ukraine of 31.10.2011 №723.

Resolution of the Cabinet of Ministers of Ukraine «On approval of the Agreement on cooperation in combating the circulation of Falsified Medicines» dated 08.12.2010, No. 1114.

Resolution of the Cabinet of Ministers of Ukraine «Some issues of State Control of quality of medicines» dated February 3, 2010 No. 260.

Resolution of the Cabinet of Ministers of Ukraine «On approval of the Criteria for assessing the risk of health care activities for the safety of life and health of the population and determining the periodicity of the planned measures of State Supervision (Control)» dated September 10, 2008 No. 843.

Although, in spite of the rather significant legal and regulatory framework for the regulation of activities in the field of manufacturing and circulation of medicines and medical products, there are widespread offenses in this area related to: manufacturing / manufacturing of medicinal facilities; manufacturing of medicines in the conditions of the pharmacy, storage and sale of medical facilities and medical products (wholesale, retail sale of medicines and medical products); which are carried out when imported into the customs territory of Ukraine (in the process of import) of medicines and medical products.

Typical offenses in the field of production / manufacture of medicines, dangerous for life and health of citizens are:

- production / manufacture of medicines which are dangerous to the health of citizens and / or of inadequate quality (whose quality does not conform to the established legal requirements) (the presence of documented facts or signs of the production of medicines which may be dangerous for the health and life of people or may lead to grave consequences for human health as a result of possible violations of production technology and / or quality control methods); 
- intentional counterfeit, curvature or falsification of medicines (presence of facts of production of counterfeit medicines);

- establishment of facts of production of the medicines not brought into the general list of nomenclature of products of enterprise-producer;

- the production of medicines without a license (absence for the subject of manage corresponding license to realization of economic activity from the production of medicines and accordance of executable works marked in this license);

- the presence in documents submitted for state registration of medicines, inaccurate or incomplete information, the disparity in these documents of the name of the manufacturer of such a medicines, the address of its location and the location of its production facilities;

- violation of the established procedure for state registration of medicines;

- an unauthenticity of information in documents, submitted by a business entity for receipt of license for the conduct of economic activity for the industrial production of medicines;

- violation of protected by the patent intellectual property rights in the manufacture of medicines;

- violations of standards and specifications, pharmacopoeial articles and technological regulations, as well as other violations during the manufacture of medicines;

- discrepancy of the composition of the medicines specified in the registration documents;

- non-inclusion of active ingredients and auxiliary substances in the finished product, that correspond to the registration dossier of the medicines for qualitative and quantitative composition (non-compliance with the qualitative and quantitative composition of the medicines specified in the registration dossier);

- not realization of the quality control of the medicines and / or its ingredients, as well as control of the intermediate stages of the production process or non-fulfillment of some other requirements or obligations;

- unjustified expansion of the range of the medicines, manufactured in certified production, which creates a risk of contamination (Latin contaminatio - crossbreeding, mixing) or cross-contamination;

- the discovery of the mismatch of the manufacture of medicines to the requirements of so-called good manufacturing practice - GMP;

- absence of material and technical base (rooms, equipment) for realization the production of medicinal at the places of economic activity of a business entity;

- impossibility to provide activity on the production of medicines on the basis of the availability of the material and technical base, which is a business entity;

- discrepancy of the information, specified in the documents on the right of ownership or the contract of lease (use) agreement for the premises (material and technical base of the enterprise), the data specified in the license for the conduct of economic activities for the production of medicines, as well as the actual state;

- lack of specialists in the manufacturer of medicines, which should have appropriate special education and meet the single qualification requirements;

- lack of pointing in relation to the type of the economic activity related to the industrial production of medicines, in the constituent documents of subject of menage;

- lack of registration certificates for medicinal facilities and their non-compliance with manufactured products; 
-the lack of conformity of the conditions of production of medicinal products with the requirements of the normative and technical documentation;

- lack of a business entity engaged in the production of medicinal facilities, documents that record: the procurement, production, storage, transportation, destruction or disposal of medicinal products;

- violation of the rules of labeling medicines;

- forgery of a trademark of a manufacturer of medicines with accordance of quality composition active substance of a falsified medicinal product for marking;

- inconsistency of the building, rooms and equipment used for conducting activities for the manufacture and / or production of medicines, by established requirements;

- non-compliance with sanitary norms and hygienic norms in the manufacture and / or production of medicines;

- activity in the pharmaceutical sphere of persons who do not meet the uniform qualification requirements.

The manufacture (production) of medicines in the conditions of the pharmacy is carried out only in pharmacies under a license for the manufacture of medicines. At the same time, the manufacture (production) of medicines in the conditions of the pharmacy should be carried out in line with the requirements of the legislation, including the Rules for the manufacture of medicines under pharmacy conditions, approved by the order of the Ministry of Health of Ukraine dated December 15, 2004 No. 626. Trade in medicines manufactured (produced) under the conditions of a pharmacy can be carried out only through pharmacies and structural subdivisions of pharmacies of the business entity that owns the pharmacy that manufactures them (produces).

Among the offenses committed in the course of the manufacture of medicines in a pharmacy, the storage and sale (sale / release) of medicines and medical products (wholesale, retail trade in medicines and medical products) that are dangerous for the life and health of citizens the following should be noted:

- storage for further sale of medicines, the quality of which does not meet the established requirements;

- failure to comply with the requirements legislation on the quality of medicines during transportation and further trade;

- sale (trade, service) to citizens of poor-quality medicines or those whose expiration date has passed or for which there is no quality certificate issued by the manufacturer or made by the pharmacy in violation of the conditions of production;

- violation of the legal requirements for the advertising of medicinal products;

- infringement of the patent protected by the current proprietary rights of intellectual property in the use, sale of medicinal products;

- violations of standards and specifications, pharmacopoeial articles and technological regulations, as well as other similar violations during the storage, transportation and sale of medicinal products;

- violation of the rules for prescribing prescriptions for medicines and medical products, which are released on preferential terms or free of charge, or for medicines the cost of which is subject to state compensation;

- certification by the healthcare institution or other business entity that carries out activities related to medical practice, which are not filled in or not signed by the medical officer of the prescription forms;

- failure to provide the property quality of medicines during the entire period of their storage, distribution and further circulation;

- the lack of conformity of a medicines with the requirements of the quality specification as a result of visual inspections; 
- Identification of discrepancies in the accompanying documents for a series of medicines;

- violation of the established conditions of storage, transportation and sale of the medicinal product, which may adversely affect its quality;

-Wholesale and retail trade in pharmaceuticals without a license;

- the implementation of remote (through the Internet) medicines trade, as well as the sale of medicines by mail and through any facilities other than pharmacies;

- storage of goods in pharmacy establishments, except for medicines and related products;

- illegal transportation of medicines together with other types of goods, except for related goods;

- unlawful transportation of medicines by public transport;

- sale of prescription medicines without a prescriptions;

- advertising (in any form) of prescription medicines;

- in case of complete termination of the pharmacy's work or its liquidation, implementation of activities through the structural subdivisions, which are subject to this pharmacy;

- unreliability of information in documents filed by a business entity for obtaining a license for the business of wholesale and retail trade in medicines;

- lack of material and technical base (premises, equipment) for the wholesale business, retail trade in medicines by places of economic activity; absence from this economic entity of specialists who have the appropriate special education and meet the same qualification requirements;

- wholesale, retail trade of low-quality / counterfeit medicines;

- circulation of overdue medicines with overprinted markings;

- sale of medicines under the guise of other goods;

- re-packaging of overdue medicines for the purpose of further implementation;

- non-compliance of the regulatory conditions for medication storage;

- improper implementation of the entrance control of medicines (which is typical for prevention and treatment institutions);

- Implementation (medical use) of medicines without a manufacturer's quality certificate;

- Implementation (medical use) of unregistered medicines with expiry date that do not conform to analytical normative documentation (AND) according to visual indicators prohibited by the requirements of the State Inspectorate of the Ministry of Health of Ukraine.

There are a number of other offenses, including those that occur when importing medicines and medical products into the customs territory of Ukraine (in the process of import) for the purpose of their further sale (trade) or use in the manufacture of finished pharmaceuticals, to this category include:

- Importation of medicines into the territory of Ukraine not registered in Ukraine;

- Importation of medicines to the territory of Ukraine without the maintenance of a certificate of quality of a series of medicinal product issued by the manufacturer;

- Importation of medicinal products into the territory of Ukraine (import) without a license for the import of medicinal products (other than AFI-active pharmaceutical ingredient) to an importer (including the manufacturer or the person representing the manufacturer of medicinal products on the territory of Ukraine);

- Importation of non-quality or falsified medicinal products into the customs territory of Ukraine; 
- supply to the customs territory of Ukraine of low-quality or falsified, or counterfeit, or improperly marked medicinal products, «in bulk» products;

- non-passage of the imported series of medicines manufactured outside Ukraine, relevant quality control in Ukraine;

- Delivery of medicines to Ukraine that expired;

- storage of non-marked, defective and high-quality imported pharmaceuticals together without further utilization or destruction;

- inconsistency with the actual name of the manufacturer of the medicinal product, its location and location of its production facilities, indicated in the information on the basis of which such a medicinal product is registered by the competent authority of the country of origin of the medicines;

- absence in the constituent documents of the business entity - the importer of medicinal products, mark on the possibility of foreign economic activity;

- lack of documentation of the quality management system, in particular standard operating procedures (SOPs), concerning the implementation by the entity of activities related to the import of medicinal products;

- the non-compliance of conditions for import of medicinal products to the requirements of normative and technical documentation;

- lack of staffing, workbooks of the business entity that imports medicines;

- absence of documents confirming the legal relations of employees with the subject of business (orders about appointment, employment contracts, etc.), which imports medicines;

- transfer of a license for conducting economic activity on the import of medicinal products or a copy thereof to another legal entity or individual for carrying out the said activity;

- inconsistency of the material and technical basis, qualifications of the personnel of the subject of business, as well as the conditions for controlling the quality of medicinal products imported into the territory of Ukraine, the requirements of regulatory documents on import, storage, quality control, wholesale trade in medicinal products or the production of medicinal products;

- the absence of an authorized person (s) from the importer of medicinal products that is (are) responsible (them) for the confirmation of the quality certificate series of the medicinal product and the authorization for its issue (implementation).

\section{Results}

In the field of manufacturing / production of medicinal products, the important factor is the protection of the life and health of citizens through the proper state regulation and control of the activities of business entities that producing and distributing medicines on the part of state controlling bodies. In order to prevent, detect and prevent the commission of offenses by state controlling bodies, a number of measures are carried out, in particular, inspections of an entity that carries out economic activity on industrial production of medicinal products are carried out. Important criteria for conducting this event are the mandatory clarification of issues concerning:

- available in the constituent documents of this entity of an indication of the type of activity carried out by the entity, namely, the activities for the production of medicinal products;

- correspondence of the information's given in the license, the correspondence specified in the company's statute, the constituent agreement, the certificate about inclusion in the National State Registry of Ukrainian Enterprises and Organization; 
- Availability of the corresponding license for conducting economic activity on the production of medicinal products and the compliance of the performed work specified in the license;

- availability copy of the license, which confirms the right of the branch or other separate entity of the entity to conduct a certain type of economic activity at the place of production, indicated in the copy of the license;

- the correspondence of the information specified in the documents on the right of ownership or the contract of lease (use) on the premises (material and technical base of the enterprise), the information specified in the license for the right to conduct economic activity on the production of medicinal products, as well as its actual state;

- availability of normative and technical documentation, documentation on the standardization of medicinal products and documentation of the quality management system, according to which it is possible to trace all the important stages of technological operations in the manufacture of medicinal products (this documentation includes specifications or analytical and regulatory documents, protocols (journals, dossiers of the series etc.), packaging, distribution, technological instructions, methods (standard operating procedures (SOPs), etc.));

- availability of registration certificates for medicines and their conformity to manufactured products;

- conformity of production conditions to requirements of normative and technical documentation;

- availability of premises, their location and order in accordance with the technological zones: production, warehouse, auxiliary zones, quality control zones;

- the location, application, arrangement of the premises in accordance with the sequence of operations of the technological process and the compliance of the auxiliary and production operations carried out there;

- availability and conformity of the necessary production equipment, technical equipment, equipment (inventory), measuring instruments to ensure the proper conduct of the technological process for the production of medicinal products;

- compliance with the requirements of the legislation on the quality of medicinal products in their production;

- availability of documents approved by a business entity that carries out economic activity on industrial production of medicinal products, technical and technological regulations or equivalent to them by the Ministry of Health of Ukraine: dossiers of the voting's station, production formulations with corresponding technological and other instructions with observance of the current requirements The State Pharmacopoeia of Ukraine and / or other normative and technical documents that establish requirements for a medicinal product, its packaging, conditions and terms for preservation and methods of quality control of medicinal product, etc.;

- availability of staffing, workbooks of employees and their respective registration;

- the presence of documents confirming the legal relations of employees with a business entity (orders about appointment, employment contracts, etc.), and their corresponding registration;

- the correspondence and timeliness of the registration of personal medical books from employees;

- availability of the required number of qualified staff, documents on special education and professional development of workers who are directly involved in the production of medicines and wholesale sales of their own products, and their compliance;

- availability of a department (subunit) to ensure quality control in the process of producing medicinal products, as well as the presence of an authorized person who is responsible for granting a permit for the implementation of medicinal products; 
- availability of a plan of urgent actions to ensure the execution of orders, requirements of the Ministry of Health of Ukraine and the State Medical Service of Ukraine regarding the suspension of production, trade, withdrawal from circulation of medicines and the use of appropriate measures to return the manufacturer (seller) of the indicated drugs or to destroy and dispose of them;

- the compliance of the medicinal products with their purpose, the requirements of the analytical normative and technological normative documentation, the registration dossier or the specifications approved by the Ministry of Health.

An undertaking conducting retail trade in medicines, must observe the requirements with the requirements of the legislation on the quality control of medicinal products and also keep at least three years the documents certifying the purchase of medicinal products, indicating the name, date, form of issue, the number, series and expiration date of the medicinal product obtained, the manufacturer, supplier information and details of his license.

According to the current legislation, only registered medicines in Ukraine are allowed in wholesale and retail trade if they have a quality certificate, that issued by the manufacturer and is stamped by the last supplier of these medicines. An entity is required to keep the manufacturer's quality certificates (copies on paper or scanned copies on electronic media) on a series of medicines, implemented by the business entity within three years from the date of purchase of the medicinal products.

Pharmacies carry out the sale of ready-made prescription and non-prescription medicines. Receipts of drugs to the pharmacy's structural units should be made only through the pharmacy to which they are subject, or through the pharmacy warehouse (base).

The order of delivery of medicinal products to the pharmacies' structural units is determined by the business entity licensed for the retail sale of medicinal products, with obligatory written registration.

Medicinal products and related products received by the pharmacy must be received after checking their actual quantity and carrying out entrance quality control no later than the next working day from the moment they are received. According to the current legislation, it is prohibited to distribute (through the Internet) drug trade, as well as the sale of medicines by mail and through any facilities other than pharmacies.

Under the current legislation, advertising of pharmaceuticals that are prescribed without a prescription and not on the list of prohibited medicines is allowed. The decision on the introduction of the medicines into a list of medicinal products, the advertising of which is prohibited, is made during the state registration (reregistration) of the medicinal product with the introduction of the relevant information in the State Register of Medicinal Products of Ukraine. Advertising of medicines, the use and selling of which is allowed only on prescription of a doctor, as well as those included in the list of prohibited for advertising, it is forbidden.

\section{Discussions}

Particular attention to the state control bodies should be applied to medicinal products imported into Ukraine, since it is in this area that there is a significant number of facts of the circulation of counterfeit, inadequate and unregistered medicines. When carrying out the state control of the quality of medicinal products imported into Ukraine, the following documents are verified:

1. Conclusion on the quality of medicines imported into Ukraine;

2. The list of medicines imported into Ukraine, where the following information is indicated: the full trade name of the medicinal product according to the registration certificate, the dosage, the form of the medicinal product, the number of the medicinal product, the name of the manufacturer, the country of manufacture, the size of the series, the amount of the imported medicinal product, the expiration date of the medicinal product, the number of the registration certificate for the medicinal product, the validity 
period of the registration certificate for the medicinal product, the number issued by the State Service of Ukraine on Medicines and Drug Control, which confirms the conformity of the conditions of production of medicinal products to the requirements for the production of medicinal products in Ukraine, the number of the customs declaration (MD), the date of issue of $M D$, number, date of the conclusion on the quality of the medicinal product imported into Ukraine (for the series of medicinal product imported repeatedly);

3. The entity's report on the results of the control of active pharmaceutical ingredients (substances) and products «in bulk».

It should also be noted, that the ways used to hit counterfeit drugs on the territory of Ukraine are usually smuggled, that is, outside or with concealment from customs control. This is not accidental, because the rules of treatment of medicines, including their movement across borders are clearly defined by law, and their observance is strictly controlled by the state. Therefore, the displacement of large, usually illegal, parties of counterfeit medicines not possible in a lawful manner, which determines the search for ways of concealing them when traveling across the border and the widespread smuggling.

The geographical location of Ukraine at the intersection of sea, land and air transport corridors from Asia to Europe, the difficult economic situation, high morbidity and mortality of the population determine both transit and domestic interests in the smuggling of counterfeit medicines. Smuggling of falsified medicines can be carried out by means of both transportation and transfer of the specified objects across the customs border of Ukraine.

To determine the composition of the criminal offence of smuggling of counterfeit medicines, should be guided not only by the provisions of Part 1 of Art. 91 CPC of Ukraine and Art. 305 of the Criminal Code of Ukraine (CC), but also norms of the general part of the Criminal Code of Ukraine. For example, these are cases, where the said criminal offense is committed by a group of persons in complicity, etc.

It should be borne in mind that the smuggling of falsified medicines is a criminal offense with a formal composition. Therefore, first, the damage caused by the said criminal offense can not always be established, and secondly, it does not matter for qualification. However, this does not mean that the damage done is negligible, and its danger decreases. On the contrary, the damage here is dual in nature. On the one hand, the goods are moved across the border in violation of customs rules. On the other hand, the goods forbidden to free sale are transferred to the territory of the state, and the violation of this regime is detrimental to the public interests and interests of the state.

The fact of smuggling falsified medicines is closely linked to the time, place and method of committing a criminal offense. Although these circumstances do not have a special significance for the qualification of smuggling of counterfeit medicines, at the same time, their establishment is a prerequisite for bringing a person to criminal liability.

Forensic practice indicates, that smugglers resort to various methods of criminal offense in order to illegally carry certain objects with concealment from customs control.

The generalization of the practice of combating this type of smuggling shows that its objects are hidden from customs control in special repositories (hiding places) equipped, adapted or located:

a) directly on the smuggling itself or in his or her personal belongings;

b) in the personal baggage of the smuggler who is located with him or follows separately;

c) in vehicles where the smuggler or his baggage crosses the customs border.

To disguise counterfeit medicines from customs control or move them across the customs border outside the spot of control, criminals use the possibilities of modern technology, scientific knowledge, imperfection of legislation, corruption links, etc. It is these circumstances that must be the subject of evidence in every criminal proceeding. 
In the case of committing smuggling falsified medicines by way of movement through the customs border outside of customs control, the task of clarifying the circumstances to be proved is the establishment of a mode of movement, namely: the type of transport of movement (water, air, rail, road transport, etc.); import or export; transfer, transfer, forwarding by international mail, etc.

In conducting a pre-trial investigation of a criminal offense under Art. 305 of the Criminal Code, the place of commission of a criminal offense - the customs border of Ukraine, namely, the customs control zone where the person was arrested, should be clearly established, as the direct place of smuggling is the zone of customs control.

The zone of customs control is determined at the points of entry through the customs border or other places of the customs territory, within the limits of customs control, namely: at the places of registration of passengers, vehicles, goods, as a rule, they have a customs room, a compartment of a wagon, an airplane board, a car inspection site, a river or sea vessel, specially designated places for customs control, inspection boxes, etc.

When moving objects of contraband (counterfeit medicines) outside the customs location, it is necessary to install:

a) the actual place of detention of the offender;

b) location of the place of detention of the offender relative to the line of the customs border;

c) the way and way of moving smuggled objects to the place of detention;

d) the actual place of crossing the customs border;

e) the place of departure and destination of contraband, the latter when moving a geographical point before crossing the customs border.

Establishing the time of commission of a criminal offense, stipulated by Art. 305 of the Criminal Code, certainly depends on the circumstances of the criminal proceedings. A special precision of time determination is necessary in the event that counterfeit medicines are moved outside the customs control points. Since in such cases the time can indicate whether there was illegal (beyond the established time of customs clearance and work of the customs authority) crossing the border with falsified medicines.

However, persons guilty of violating the legislation on medicinal products are subject to disciplinary, administrative, civil or criminal liability for other types of offenses in accordance with the legislation of Ukraine.

Article 321-1 of the Criminal Code "Falsification of medicinal products or circulation of counterfeit medicines» for the manufacture, acquisition, transportation, forwarding, storage for the purpose of sale or sale of deliberately falsified medicines shall be punishable by deprivation of liberty for a term of three to five years. The same actions committed repeatedly or by prior conspiracy by a group of persons, or in large quantities, or if they caused a prolonged disorder in the health of a person, as well as the production of counterfeit medicines, shall be punishable by imprisonment for a term of five to eight years with confiscation property. And the actions provided for in parts one or two of the aforementioned article, if they caused the death of a person or other grave consequences, or committed in particularly large proportions, shall be punishable by imprisonment for a term of eight to ten years, or by life imprisonment, with the confiscation of property.

A person who has voluntarily passed counterfeit medicines and indicated the source of their purchase or facilitated the disclosure of crimes related to their circulation is exempted from criminal liability for the purchase, transportation, transfer or storage for the purpose of sale, sale of deliberately falsified medicines, their importations on territory of Ukraine, export from the territory of Ukraine, transit through its territory (part one of Article 321-1 of the Criminal Code, if such actions have not created a threat to life or health of people). 
This criminal offense is often committed in conjunction with other crimes such as illegal entrepreneurship; violation of copyright and related rights; concealment of income from taxation; bribery; fraud.

Article 321-2 of the Criminal Code of Ukraine «Violation of the established procedure for preclinical study, clinical trials and state registration of medicines» provides for criminal liability for intentional violation of the established procedure of preclinical study, clinical trials of medicinal products, falsification of their results, as well as violations of the established procedure for state registration of medicinal products, punishable by imprisonment for a term of three to five years, with the deprivation of the right to occupy certain positions or engage in certain activities for one to three years.

The same actions committed repeatedly or by a prior conspiracy by a group of persons - shall be punishable by imprisonment for a term of five to eight years, with the deprivation of the right to occupy certain positions or engage in certain activities for a term of two to three years.

Actions provided for in parts one or two of the article. 321-2 of the Criminal Code, if they caused the death of the victim or other grave consequences, - shall be punishable by imprisonment for a term of eight to ten years with the deprivation of the right to occupy certain positions or engage in certain activities for a term of two to three years.

The Criminal Code of Ukraine contains articles that provide for liability for violations of intellectual property rights, in particular, in our case, in the sphere of production and circulation of medicines. Thus, according to Part 1 of Art. 177 of the Criminal Code «Violation of the rights to an invention, useful model, industrial design, topography of the integrated circuit, plant variety, rationalization proposal»; illegal use of the invention, utility model, industrial design, topographies of the integrated circuit, plant variety, innovation proposal, appropriation of authorship on them, or another deliberate violation of the right to these objects, if it caused material damage to a significant extent, provides for punishment in the form of a fine from two hundred to one thousand tax-free minimum incomes of a citizen or correctional labor for up to two years, or imprisonment for the same term.

Actions provided for in Part 2 of the above-mentioned article of the Criminal Code of Ukraine, if they are repeatedly committed, or by conspiracy of persons, or have caused material damage to a large extent, shall be punishable by a fine of from one thousand to two thousand non-taxable minimum incomes, or correctional labor for a term up to two years, or by deprivation of liberty for a term of two to five years.

At the same time, the actions envisaged by the parts of the first or second item. 177 of the Criminal Code, if committed by an official through abuse of office or an organized group or if they caused material damage on a large scale, punishable by a fine of two thousand to three thousand non-taxable minimum incomes, or imprisonment for a term of three to six years, with disqualification the right to occupy certain positions or engage in certain activities for a term up to three years or without such.

In addition, according to Art. 229 of the CC «Unlawful use of the mark for goods and services, brand name, qualified indication of the origin of goods", the illegal use of the mark for goods and services, trade name, qualified mark of origin of goods, or other intentional violation of the right to these objects, if it caused material damage to a significant extent, shall be punishable by a fine of one thousand to two thousand nontaxable minimum incomes of citizens.

The same actions, if committed repeatedly, or by a prior conspiracy by a group of persons, or they caused material damage to a large extent, shall be punishable by a fine of three thousand to ten thousand nontaxable minimum incomes of citizens.

Actions foreseen by parts one or two 229 of the Criminal Code, committed by an official using an official position or an organized group, or if they caused material damage in a particularly large amount, shall be punishable by a fine of ten thousand to fifteen thousand non-taxable minimum incomes of citizens with the deprivation of the right to occupy certain positions or engage in certain activities on up to three years or less. 
The following widespread violations in the area of intellectual property in the process of production and circulation of medicinal products can be found: unlawful use of trademark offenders, inventions, utility models and industrial designs that have received legal protection on the basis of their state registration and rights to which patents and certificates are protected by the right to medicines (formula of the medicinal product, packaging, label on the medicinal product, method of treatment, etc.)

Criminal proceedings involving of violations of intellectual property rights may be instituted only upon application of the copyright holder of intellectual property rights. If he has not lodged such a request with law enforcement agencies, even if there is a violation of the rights to intellectual property objects, it is impossible to initiate a criminal proceeding.

In addition, the possibilities for liability for counterfeiting of medicines, which is one of the varieties of counterfeiting, have a limited period of legal protection granted by patents for inventions, utility models and industrial designs.

Article 42-4 of the Code of Administrative Offenses of Ukraine provides for administrative liability for the sale of medicines in pharmacy establishments without a prescription in cases prohibited by law, which entails a fine of six to twenty-five tax-free minimum incomes of citizens.

Failure to comply with standards, norms, rules and specifications during the production, storage, transportation, sale or use of medicinal products (Articles 167-170 of the CUUP), in particular:

- Art. 167 of the Code of Administrative Offenses of Ukraine «Putting into circulation or selling products that does not meet the requirements of standards», which provides for administrative responsibility for putting into circulation (release to the market of Ukraine) or the sale of products (in our case, of medicines) that does not meet the requirements of standards, certificates compliance, norms, rules and samples (standards) with regard to safety, quality, completeness and packaging (except in cases stipulated by the legislation of Ukraine), which entails the imposition of a fine on officials of enterprises, institutions, organizations regardless of ownership, and citizens - owners or their authorized representatives from twenty to one hundred times the income;

- Art. 168-1 of the Code of Administrative Offenses of Ukraine «Execution of works, providing services to citizens-consumers that do not meet the requirements of standards, norms and rules», which provides for administrative responsibility for the execution of works, provision of services to citizens-consumers that do not meet the requirements of standards, norms and rules that imposes a fine on officials, citizens engaged in entrepreneurial activities, from one to eighteen non-taxable minimum incomes of citizens;

- Art. 170 of the Code of Administrative Offenses of Ukraine «Non-compliance with standards for the transportation, storage and use of products (except foodstuffs)", which establishes administrative responsibility for non-observance of standards and technical conditions during transportation, storage and use (exploitation) of products (in our case, medicinal products), if it is caused a decrease in the quality, damage or excessive loss of production, which results in the imposition of a fine on officials from three to forty non-taxable minimum incomes of citizens.

-Article 188-10 of the Code of Administrative Offenses of Ukraine «Failure to comply with the lawful requirements of officials of the central executive body implementing the state policy in the field of quality control and safety of medicines» provides for administrative liability for non-fulfillment of legal requirements of officials of the main executive body, which implements state policy in the field of quality control and safety of medicines (the State Service of Ukraine on Medicines and Drugs Control), to eliminate violations of the legislation on medicines or to create obstacles to their activities, which will be superimposed ranging from ten to twenty times the income.

In of the Code of Administrative Offenses of Ukraine there are also Art. 244-8, which establishes the powers of the central executive authority, which implements the state policy in the field of quality control and safety of medicines, which states that the central executive body implementing the state policy in the field 
of quality control and safety of medicines (State Service of Ukraine on Medicines and Drugs Control) examines cases of administrative violations, in particular, related to the sale of medicinal products without prescription in cases prohibited by law (Article 42-4), non-compliance with requirements of standards, norms and rules the technical conditions for the production, storage, transportation, sale or use of medicines (Articles 167-170), as well as the non-fulfillment of legal requirements of officials of the central executive authority, which implements the state policy in the field of quality control and safety of medicinal products (Article $188-10$ ).

The Ministry of Health of Ukraine dated October 26, 2001 approved the Instruction (No. 428) on registration of materials on administrative violations of the legislation of Ukraine regarding the quality assurance of medicinal products. As a result, the procedure for conducting proceedings in administrative offenses in the pharmaceutical sphere is determined by the Code of Ukraine on administrative offenses and specified by the Instruction.

To the Protocol on administrative offenses in pharmaceutical activities, drawn up by an official of the State Service of Ukraine on Medicines and Drugs Control, materials are attached that confirm the fact of committing an administrative offense:

- acts on the results of verification of the compliance of the subject of economic activity with the requirements of legislation on the quality assurance of medicines;

- acts of sampling a medicinal product for laboratory testing of their quality;

- an order for the prohibition (manufacture in pharmacy conditions, sale, trade, storage, transportation, use) of a medicinal product;

- an order on the suspension or prohibition of the production of medicinal products;

- urgent reports on the detection of substandard, falsified or unregistered medicines;

- a statement on the elimination of violations of the Ukrainian legislation on medicines.

In the State Service of Ukraine on Medicine's and Drugs Control, and its each territorial body is kept logs of administrative offenses related to non-compliance with the requirements of standards, norms, rules and specifications during the production, storage, transportation, sale, sale or use of medicinal products.

Article 164-14 of the Code of Ukraine on Administrative Offenses «Violation of procurement law» provides for administrative liability for the procurement of goods, works and services without the use of procurement procedures determined by law; evaluation of offers of competitive bids (qualifying proposals), tenders not according to the criteria and methodology of evaluation to determine the best offer of competitive bidding (qualifying proposal), tender offer contained in the documentation of competitive bidding (qualification documentation), tender documentation; conclusion with the tenderer who has become the winner of the bidding, the contract on the purchase at prices and volumes that do not meet the requirements of the documentation of competitive bidding (qualification documentation), tender documentation; non-disclosure or violation of the procedure for the publication of procurement information in accordance with the requirements of the legislation; failure to provide information, documents and materials in cases stipulated by law, which entails the imposition of a fine on officials (officials), authorized persons from seven hundred to one thousand non-taxable minimum incomes of citizens.

In particular, responsibility in the field of public procurement of medicines may be borne by the members of the tender committee of the customer, the authorized person (s), members of the appeal body, officials of the Authorized Agency (of the Ministry of Health of Ukraine), service (officials) of the bodies carrying out treasury servicing of budget funds (servicing bank). 


\section{Conclusions}

The most frequent encroachment on the life and health of citizens in the sphere of manufacturing and circulation of medicines and medical products is by means of counterfeiting of medicines which are in daily demand and advertised on television and radio; they include painkillers, antibiotics, psychotropic substances.

There are a number of factors contributing to the commission of offenses in the sphere of production (manufacturing), storage, sales (realizations), import of medicines. One of the factors behind the spread of counterfeit medicines is the availability of modern equipment, in particular polygraphic, which allows producing counterfeits of such a high quality that it is virtually impossible to distinguish falsely from this medicinal product on the outside. Accordingly, there is a widespread increase in the illegal production of medicines, which is characterized by a significant level of latency.

In addition, widespread wrong labelled medicines, smuggling, sale of substandard (insufficient quality) and unregistered pharmaceuticals and medicines of a precarious production or they have a different purpose (including technical) and therefore cannot be used for treatment.

Also, falsification of medicines promotes the sale of medicines through the Internet, which cannot be checked for quality and find a supplier, despite the prohibition in Ukraine of online pharmacies. The Internet Network is a fairly attractive market for those medicines that have not undergone clinical trials and procedures for state registration, and therefore cannot be implemented on its domestic market. At the same time, through online pharmacies, even prescription medicines are sold.

The sphere of public procurement of medicines remains the most corrupted area of public relations. Thus, the most widespread type of crime in the health sector is theft of budget funds by excessive prices on markets prices, when organizing the purchase of medicines, products and medical equipment for health care institutions. The most widespread corruption schemes for public procurement of medicines in Ukraine are the so-called "cartel conspiracies», in other words, behind-the-scenes agreements between companies on the distribution of winning bidding and excess pricing of medicines in the State Register of wholesale and retail prices.

All considered violations require the development of a clear regulatory mechanism at the legislative and regulatory levels of the processes of production, control and marketing of medicinal products; only such actions will contribute to counteracting fraud and illicit circulation of falsified medicines and will provide protection of life and health of citizens.

\section{References}

Approved by the decision of the Accounting Chamber. (n.d.). Report on the results of the audit of the effectiveness and reasonableness of the application of tax deductions for value added tax on the operations of supplying and importing medicines and medical products into the customs territory of Ukraine. Retrieved from http://www.ac-rada.gov.ua/doccatalog/document/16756087/Zvit_4-6_2018.pdf?subportal=main

State Service of Ukraine on Medicines and Drugs Control. (2018). Report on the results of the activity of the State Service of Ukraine for Drugs and Drug Control in 2018: Держлікслужба. Retrieved February 19, 2020, from http://dls.gov.ua/activity_results/\%D0\%B7\%D0\%B2\%D1\%96\%D1\%82-\%D0\%BF\%D1\%80\%D0\%BE\%D0\%BF\%D1\%96\%D0\%B4\%D1\%81\%D1\%83\%D0\%BC\%D0\%BA\%D0\%B8\%D0\%B4\%D1\%96\%D1\%8F\%D0\%BB\%D1\%8C\%D0\%BD\%D0\%BE\%D1\%81\%D1\%82\%D1\%96\%D0\%B4\%D0\%B5\%D1\%80\%D0\%B6\%D0\%B0\%D0\%B2\%D0\%BD/

Law of Ukraine dated 04.04.1996 No. 123/96-VR (as amended) «On Medicinal Products». Retrieved from https://zakon.rada.gov.ua/laws/show/123/96-\%D0\%B2\%D1\%80 
On Public Procurement. (2015). Retrieved from https://eupublicprocurement.org.ua/wpcontent/uploads/2016/03/PPL-No.-922-of-25-December-2015-ENG.pdf

The Ukrainian government approved medicines procurement under the 2018 budget funds. (n.d.). Retrieved from https://en.moz.gov.ua/article/news/the-ukrainian-government-approved-medicines-procurement-underthe-2018-budget-funds-.

Procedure for state registration (re-registration) of medicinal products and amounts of fees for their state registration (re-registration), approved by the Resolution of the Cabinet of Ministers of Ukraine dated May 6, 2005 No. 376 (as amended).

On approval of the form and description of the registration certificate for a medicinal product. (n.d.). Retrieved from https://zakon.rada.gov.ua/laws/show/z0742-09

Order of The Ministry Of Health Of Ukraine. (2015). Retrieved from https://cislegislation.com/document.fwx?rgn=89438

On the Procedure for Procurement of Medicines by Public Healthcare Institutions Financed from the Budget. (1996). Retrieved from https://zakon.rada.gov.ua/laws/show/1071-96-\%D0\%BF

Procedure for confirming the conditions of production of medicinal products to the requirements of proper industrial practice. (2012). Retrieved from https://zakon.rada.gov.ua/laws/show/z0133-

13/ed20121227?lang=en

Rules for prescribing prescriptions for medicines and medical products, the Procedure for the dispatch of medicinal products and medical products from pharmacies and their structural subdivisions, the Instruction on the order of storage, registration and destruction of prescription forms, approved by the Order of the Ministry of Health dated 19.07.2005 No. 360.

Regulation on the State Register of Medicinal Products, approved by the Resolution of the Cabinet of Ministers of Ukraine dated March 31, 2004 No. 411.

Regulation on the State Service of Ukraine on Medicines and Drugs Control, approved by the Resolution of the Cabinet of Ministers of Ukraine dated August 12, 2015 No. 647.

Regulation on the National List of Essential Medicines and the Regulation on the Expert Committee on the Selection and Use of Essential Medicines, approved by the Order of the Ministry of Health dated February 11, 2016 No. 84.

Resolution of the Cabinet of Ministers of Ukraine dated September 5, 1996 No. 1071 «On the Procedure for Purchasing Medicines by Health Care Bodies and Institutions Financed from the Budget».

Procedure for Conducting the State Register of Medicinal Products of Ukraine, approved by the Order of the Ministry of Health of Ukraine dated 08.05.2014 No. 314.

Procedure for Import, Supply and Use of Medicines, Medical Products Exempted from the Taxation of Value Added Tax, approved by the Resolution of the Cabinet of Ministers of Ukraine dated 02.12.2015 No. 1153.

Order of the Cabinet of Ministers of Ukraine dated November 4, 2015 No. 1396-r «On the Purchase of Medicines, Medical Products and Related Services with the Involvement of Specialized Procurement Organizations».

Order of the Ministry of Health dated November 3, 2015 No. 1121 «On Approval of the Procedure for Conducting an Examination on the Authenticity of Registration Materials for a Medicinal Product Submitted for State Registration with a View to its Purchase by a Specialized Organization ».

Resolution of the Cabinet of Ministers of Ukraine dated October 28, 2015 No. 943 "Some Issues of the Payment for Medicines and Medical Products with the Involvement of Specialized Procurement Organizations». 
Resolution of the Cabinet of Ministers of Ukraine dated 08.10.2015 No. 787 «On Approval of the List of Medicines and Medical Products Procured on the Basis of Purchase Agreements (Contracts) with Specialized Procurement Organizations».

Resolution of the Cabinet of Ministers of Ukraine dated April 23, 2014 No. 117 "On the Prepayment of Goods, Works and Services Procured for Budgetary Funds».

Procedure for the State Control of the Quality of Medicinal Products Imported into Ukraine, approved by the Resolution of the Cabinet of Ministers of Ukraine dated 14.09.2005 No. 902.

Procedure for Conducting Clinical Trials of Medicinal Products and Examination of Materials of Clinical Trials, Approved by the Order of the Ministry of Health of September 23, 2009 No. 690 (as amended by the Order of the Ministry of Health of Ukraine dated 12.07.2012 No. 523).

Procedure for Verification before Issuing a License for Conducting Economic Activities for the Import of Medicinal Products, approved by the Order of the Ministry of Health of Ukraine dated February 27, 2013 No. 168.

Licensing Conditions for Conducting Economic Activity on Import of Medicinal Products, approved by the Order of the Ministry of Health of Ukraine dated February 20, 2013 No. 143.

Procedure for Monitoring Compliance with the Licensing Conditions for Conducting Business Activities in the Production of Medicinal Products, Wholesale, Retail Trade in Medicinal Products, approved by the Order of the Ministry of Health of Ukraine dated October 31, 2011 No. 724.

Procedure for Verification before Issuing a License for the Conduct of Business Activities in the Production of Medicinal Products, Wholesale, Retail Trade in Medicinal Products, approved by the Order of the Ministry of Health of Ukraine dated 11.07.2012 No. 513.

Procedure for Conducting Sectoral Certification of Laboratories for Control of Quality and Safety of Medicinal Products, approved by the Order of the Ministry of Health of Ukraine dated 14.01.2004 No. 10.

Order of the Ministry of Health of Ukraine dated January 21, 2013 No. 39 «On Approval of Forms of Documents Applicable to the State Control of the Quality of Medicinal Products Imported into Ukraine».

Procedure for Certification of the Quality of Medicinal Products for International Trade and Confirmation for the Active Pharmaceutical Ingredients that are Exported, approved by the Order of the Ministry of Health of Ukraine dated 07.12.2012 No. 1008.

Procedure for Conducting Examination of Materials for Medicinal Products Submitted for State Registration (Re-registration), as well as Examination of Materials on Making Changes to Registration Materials During the Validity of the Registration Certificate, approved by the Order of the Ministry of Health of Ukraine dated 26.08.2005 No. 426.

Licensing Conditions for Conducting Economic Activity on Production of Medicinal Products, Wholesale, Retail Trade in Medicinal Products, approved by the Order of the Ministry of Health of Ukraine dated 31.10.2011 No. 723.

Resolution of the Cabinet of Ministers of Ukraine dated 08.12.2010 No. 1114 «On Approval of the Agreement on Cooperation in Combating the Circulation of Falsified Medicinal Products».

Resolution of the Cabinet of Ministers of Ukraine dated February 3, 2010 No. 260 «Some Issues of State Quality Control of Medicinal Products».

Resolution of the Cabinet of Ministers of Ukraine dated September 10, 2008 No. 843 "On Approval of the Criterion for Assessing the Risk of Health Care Activities for the Safety of Life and Health of the Population and Determining the Periodicity of Implementation of Planned Measures of State Supervision (Control) ". 